\title{
Is Student Knowledge of Anatomy Affected by a Problem-Based Learning Approach? A Review
}

\author{
Jonathan M Williams \\ Bournemouth University, School of Health and Social Care, Bournemouth, Dorset, UK.
}

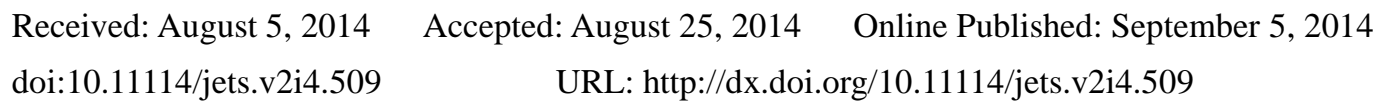

\begin{abstract}
A fundamental understanding of anatomy is critical for students on many health science courses. It has been suggested that a problem-based approach to learning anatomy may result in deficits in foundation knowledge. The aim of this review is to compare traditional didactic methods with problem-based learning methods for obtaining anatomy knowledge. A Medline search was completed and studies needed to investigate the effects of a problem-based learning method compared with an alternate method with the primary outcome being examination scores to be included. Ten articles matched the inclusion criteria. Most studies investigated undergraduate medical students. Four studies demonstrated improved exam results following a problem-based learning approach and five demonstrated no difference between didactic and problem-based learning. Overall a problem-based approach appears not to offer disadvantages or benefits over a more traditional didactic approach, however it has been suggested that additional skills, such as problem solving may be developed when using this approach.
\end{abstract}

Keywords: Problem-based, Anatomy, Review

\section{Introduction}

The fundamental understanding of anatomy is critical to students of many health science courses. Therefore the development of effective teaching and learning with regards to anatomy is paramount in higher education. To this end variation in the optimal approach to anatomy teaching and learning has been proposed. Traditionally anatomy has been taught in a lecturer led, didactic approach whilst the more modern approach of Problem Based Learning is gaining popularity. Problem Based Learning (PBL) involves students working self-directed usually in small groups using a (clinical) problem as the driver to seek knowledge (Colliver 2000). In such an approach lecturers serve as facilitators who attempt to guide students to take responsibility for their learning (Slavich and Zimbardo 2012). This approach enables students to explore problems and engage directly with alternate views likely to be held within the group. Such approaches are believed to provide better integration of knowledge (Prince et al. 2003) as well as fostering the skills of academic self-efficacy and problem solving (Koh et al. 2008). As anatomical knowledge will aid competence in clinical practice, the integration of such learning into clinical contexts is a desirable goal. Therefore the idea of a PBL curriculum for anatomy education is, on the surface, appealing. However it may be argued that the learning of factual information, such as anatomy, where there is often a definitive right and wrong answer is not best suited for lengthy group discussion and debate. In light of this, some authors have expressed concerns that a PBL approach to anatomy leaves students deficient in anatomical knowledge (Bergman et al. 2011; Prince et al. 2003). Indeed most of the focus on the benefits regarding PBL relating to anatomy has been on the attributes it develops such as life-long learning skills (Dolmans et al. 2005) and there has been little focus on actual attainment of knowledge.

The aim of this article was to review the effect of PBL based programmes on anatomy knowledge by directly comparing summative outcomes with more traditional curriculum approaches. This manuscript will review the literature directly comparing a PBL curriculum with a more traditional didactic approach for the development of anatomy knowledge in higher education.

\section{Methods}

A Medline search was conducted using the terms 'anatomy' and 'PBL'. Titles and abstracts were reviewed for specific content (see figure 1, flow chart below for retrieval numbers). To be included in this review studies needed to investigate the effects of a PBL method compared with an alternate method with the primary outcome relating to examination scores. Studies just reporting student satisfaction or faculty feedback were not included. Searches were 
limited to 1948 - 2012 (English language only). Ten studies meeting the above criteria were identified and are outlined in table 1 .

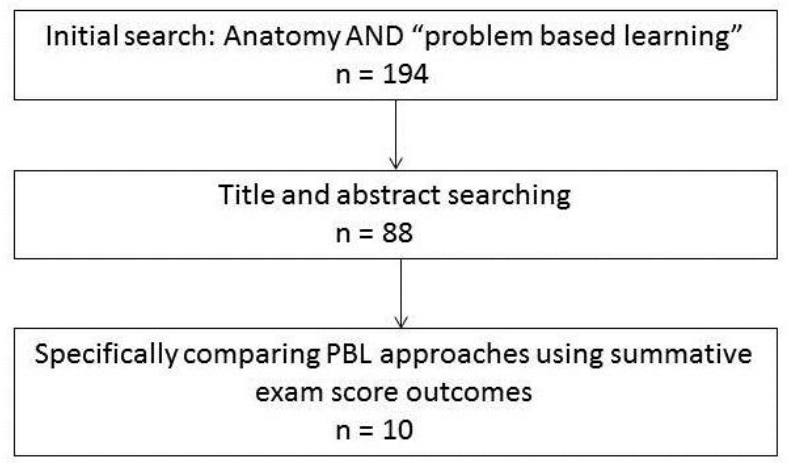

Figure 1. Flow chart for manuscript retrieval.

\section{Results and Discussion}

Eight of the studies reviewed (80\%) investigated medical students (Prince et al. 2003; Nieder et al. 2005; Adibi et al. 2007; Khaki et al. 2007; Cowan et al. 2010; Khalil et al. 2010; Azer et al. 2011; Vasan et al. 2011) with the remaining two investigating dentists (Last et al. 2001) and medical graduates and physiotherapists (Loffler et al. 2011). All but one study $(90 \%)$ were targeting undergraduate education. This is important as undergraduates may have more experience with traditional teaching and learning styles from school and further education whereas it is possible that postgraduate individuals have developed a significant amount of learning from clinical 'mileage' or experiential learning, which is therefore not attributable directly to teaching methods.

PBL activities varied across the studies ranging from team based learning approaches to self-directed learning modules. This is relevant as it highlights some of the difficulties in defining exactly what PBL is or indeed is not. Despite this most studies (90\%) did compare their PBL style approach with a more easily defined traditional didactic approach. A discussion of whether tasks to promote 'active learning' or class participation are PBL even though they may be given in lectures is beyond the scope of this review.

Six of the studies (60\%) compare a new PBL curriculum against previous intakes on a more traditional curriculum (Last et al. 2001; Nieder et al. 2005; Khaki et al. 2007; Cowan et al. 2010; Khalil et al. 2010; Vasan et al. 2011). This approach offers unique insights as many of the other cofounding variables are controlled for. For example the academic staff who delivered the traditional curriculum matches the staff delivering the PBL curriculum. This is important as differing lecturers may afford differing outcome based on the talents of some staff to encourage engagement with the material. It also provides encouragement to other schools considering a switch from traditional to more PBL who feel specialist staff maybe required. These studies demonstrate that this is not the case. However it is interesting to note that Vasan and colleagues (2011) chose to omit the data from 2004 stating that this was a transitional or pilot year. This may suggest a level of consolidation is required for the first year such a new curriculum is instigated. Such methodology also yields consistency in environmental factors such as class sizes, rooms and resources. The overall results from these studies show some benefits from PBL teaching (Khaki et al. 2007; Cowan et al. 2010; Vasan et al. 2011) where an overall $8-17 \%$ increase in average scores would be expected. However in contrast to this, others demonstrate no additional benefit to a PBL approach (Last et al. 2001; Khalil et al.2010; Nieder et al. 2005). It is interesting to note that only one study demonstrated that PBL resulted in poorer outcomes compared with more traditional curriculum (Adibi et al. 2007).

Nine of the studies (90\%) use multiple choice questions in order to access the main outcome of success from a PBL curriculum (Last et al. 2001; Prince et al. 2003; Nieder et al. 2005; Adibi et al. 2007; Khaki et al. 2007; Khalil et al. 2010; Azer et al. 2011; Loffler et al. 2011; Vasan et al. 2011). Anatomy is traditionally seen as a factual subject where clear right and wrong answers are the norm. This approach to testing knowledge is of great interest as it is geared predominantly towards intended learning outcomes which are unistructural (Anderson and Krathwohl 2001), that is they test the ability to memorise or recite factual information. Anatomy for the healthcare professional is not a standalone topic rather it must be integrated with other aspects of the course and future study, so called horizontal and vertical integration. This method of assessment may therefore fail to explore some of the key aspects associated with a PBL method. However, despite these limitations the results of the studies illustrate that even for MCQ styles tests, PBL approaches result in improved scores compared to traditional approaches in 3 studies (Khaki et al. 2007; Loffler et al. 2011; Vasan et al. 2011) or no discernible difference in 5 studies (Last et al. 2001; Prince et al. 2003; Nieder et al. 2005; Khalil et al. 2010; Azer et al. 2011). Therefore despite the assessment perhaps favouring the evaluation of superficial 
knowledge, those on a PBL curriculum were not disadvantaged. Those studies not solely relying on MCQ or short answer examinations (Vasan et al. 2011; Cowan et al. 2010) a clearer picture in favour of better performances following PBL methods emerge, however with such a small number of studies any firm conclusions should be adopted with caution. It would be of interest to compare teaching approaches by assessing the development of more integrated anatomy knowledge formation which more closely aligns the future role of the healthcare professional and this may affect the conclusions drawn from PBL.

Table 1. Table comparing key features of the article included in this review.

\begin{tabular}{|c|c|c|c|c|c|}
\hline Author & Participants & Details & Outcomes & Results & Comments \\
\hline $\begin{array}{l}\text { Adibi et } \\
\text { al. } 2007\end{array}$ & $\begin{array}{l}37 \text { medical } \\
\text { students }\end{array}$ & $\begin{array}{l}\text { Direct group comparison: } \\
\text { Grp. } 1 \text { Lecture and hands on } \\
\text { practical } \\
\text { Grp. } 2 \text { Lecture, Cased-based } \\
\text { and PBL }\end{array}$ & $\begin{array}{l}65 \mathrm{MCQ} \text { exam of } \\
\text { theoretical anatomy }\end{array}$ & $\begin{array}{l}\text { Significant difference } \\
\text { (t-test; } p<0.05: \\
\text { Grp. } 1=46.4 \\
\text { Grp. } 2=41.4\end{array}$ & Both could be considered PBL \\
\hline $\begin{array}{l}\text { Azer } \\
2011\end{array}$ & $\begin{array}{l}144 \text { first year } \\
\text { medical students }\end{array}$ & $\begin{array}{l}\text { Direct group comparison: } \\
\text { Grp. } 1 \text { Text learning and } \\
\text { drawing } \\
\text { Grp. } 2 \text { Text learning and short } \\
\text { answer questions }\end{array}$ & $\begin{array}{l}15 \mathrm{MCQ} \text { exam pre } \\
\text { and post learning } \\
\text { intervention }\end{array}$ & $\begin{array}{l}\text { No significant } \\
\text { difference between } \\
\text { groups (t-test): } \\
\text { Pre: } \\
\text { Grp. } 1=6.0 \\
\text { Grp. } 2=6.4 \\
\text { Post: } \\
\text { Grp. } 1=10.1 \\
\text { Grp. } 2=8.2\end{array}$ & $\begin{array}{l}\text { Both groups SML. } \\
\text { Immediate post-test after } \\
\text { intervention. }\end{array}$ \\
\hline $\begin{array}{l}\text { Cowan } \\
\text { et al. } \\
2010\end{array}$ & $\begin{array}{l}40 \text { first year } \\
\text { medical students }\end{array}$ & $\begin{array}{l}\text { Sequential curriculum } \\
\text { comparison. } \\
\text { Structured SML in laboratory } \\
\text { introduced with scores } \\
\text { compared to previous years }\end{array}$ & $\begin{array}{l}\text { Moodle survey and } \\
\text { OSPE }\end{array}$ & $\begin{array}{l}\text { Average scores } \\
\text { increased significantly } \\
\text { by } 12 \%(\mathrm{p}<0.05) \text { and } \\
17 \%(\mathrm{p}<0.05)\end{array}$ & $\begin{array}{l}\text { Student felt that SML not } \\
\text { adequate replacement for } \\
\text { lectures. } \\
\text { Increase time spent learning } \\
\text { anatomy. }\end{array}$ \\
\hline $\begin{array}{l}\text { Khaki et } \\
\text { al. } 2007\end{array}$ & $\begin{array}{l}89 \text { first year } \\
\text { medical students }\end{array}$ & $\begin{array}{l}\text { Sequential curriculum } \\
\text { comparison. } \\
\text { Half semester traditional } \\
\text { teaching, } \\
\text { Half PBL. }\end{array}$ & $\begin{array}{l}10 \text { descriptive } \\
\text { questions, } 20 \text { yes/no } \\
\text { questions, } 30 \mathrm{MCQ}\end{array}$ & $\begin{array}{l}\text { Significant difference } \\
\text { between scores (t-test; } \\
\text { p<0.05) } \\
\text { Trad. }=63.3 \% \\
\text { PBL }=71.6 \%\end{array}$ & $\begin{array}{l}\text { Student felt PBL gave them } \\
\text { more knowledge, increased } \\
\text { creativity and aided } \\
\text { understanding compared to } \\
\text { traditional }\end{array}$ \\
\hline $\begin{array}{l}\text { Khalil et } \\
\text { al. } 2010\end{array}$ & $\begin{array}{l}40 \text { first year } \\
\text { medical students }\end{array}$ & $\begin{array}{l}\text { Self-learning modules } \\
\text { compared to modules with } \\
\text { traditional approaches }\end{array}$ & $130 \mathrm{MCQ}$ & $\begin{array}{l}\text { No significant } \\
\text { difference (t-test). }\end{array}$ & $\begin{array}{l}\text { Student scored well on SML } \\
\text { related topics. }\end{array}$ \\
\hline $\begin{array}{l}\text { Last et } \\
\text { al. } 2001\end{array}$ & $\begin{array}{l}\text { Second year dental } \\
\text { students across } \\
\text { sequential years }\end{array}$ & $\begin{array}{l}\text { Direct curriculum comparison } \\
2 \text { years }(n=101) \text { didactic } \\
\text { course. } \\
2 \text { years }(n=109) \\
\text { PBL introduced. }\end{array}$ & $40 \mathrm{MCQ}$ & $\begin{array}{l}\text { No significant } \\
\text { difference between } \\
\text { groups (Friedman test) }\end{array}$ & $\begin{array}{l}\text { Difference exists if only } \\
\text { positively marked. }\end{array}$ \\
\hline $\begin{array}{l}\text { Loffler } \\
\text { et } \\
\text { al.2011 }\end{array}$ & $\begin{array}{l}\text { Medical graduates } \\
\text { and } \\
\text { physiotherapists }\end{array}$ & $\begin{array}{l}\text { Direct group comparison } \\
\text { One group active learning. } \\
\text { One group independent } \\
\text { reading }\end{array}$ & $\begin{array}{l}\text { One week after } \\
\text { intervention }\end{array}$ & $\begin{array}{l}\text { Significant difference } \\
\text { between groups } \\
(\text { ANOVA; } \mathrm{p}<0.0005) \\
\text { Active grp. }=23.3 \\
\text { Independent grp }=19.8\end{array}$ & Interactive learning took longer \\
\hline $\begin{array}{l}\text { Nieder et } \\
\text { al. } 2005\end{array}$ & $\begin{array}{l}95 \text { first year } \\
\text { medical students }\end{array}$ & $\begin{array}{l}\text { Sequential curriculum } \\
\text { comparison } \\
\text { Old traditional curriculum } \\
\text { compared to TBL }\end{array}$ & $\begin{array}{l}100 \mathrm{MCQ}, \text { practical } \\
\text { exam and } 50 \text { short } \\
\text { answer questions }\end{array}$ & $\begin{array}{l}\text { No significant } \\
\text { differences (ANOVA) }\end{array}$ & $\begin{array}{l}\text { Less failures in TBL } \\
\text { curriculum }\end{array}$ \\
\hline $\begin{array}{l}\text { Prince et } \\
\text { al. } 2003\end{array}$ & $\begin{array}{l}4^{\text {th }} \text { year students } \\
\text { across all } 8 \\
\text { medical schools in } \\
\text { Holland }(n=411)\end{array}$ & $\begin{array}{l}\text { Across school comparison } \\
\text { Some school use PBL for } \\
\text { anatomy and others don't. }\end{array}$ & $\begin{array}{l}16 \text { case studies with } \\
142 \text { items including } \\
\text { MCQ, T/F, open } \\
\text { ended }\end{array}$ & $\begin{array}{l}\text { No significant } \\
\text { difference in knowledge } \\
\text { for those on PBL } \\
\text { curriculum (ANOVA). }\end{array}$ & \\
\hline $\begin{array}{l}\text { Vasan et } \\
\text { al. } 2011\end{array}$ & Medical students & $\begin{array}{l}\text { Sequential curriculum } \\
\text { comparison. } \\
\text { Old curriculum of traditional } \\
\text { teaching was compared to } \\
\text { following years on TBL }\end{array}$ & $\begin{array}{l}\text { MCQ exams and the } \\
\text { National Board of } \\
\text { Medical Examiners } \\
\text { exam }\end{array}$ & $\begin{array}{l}\text { Significant differences } \\
\text { were noted (?t-test; } \\
\text { p }<0.05) \\
\text { Trad }=73 \% \\
\text { TBL }=81-86 \% \\
\text { NBME } \\
\text { Trad }=64 \% \\
\text { TBL }=72-80 \%\end{array}$ & \\
\hline
\end{tabular}

MCQ; multiple choice questionnaire, SML; self-managed learning, OSPE; objective structured practical exam, Grp; Group, Trad; Traditional, TBL; team based learning, T/F; true-false, NBME; National Board of Medical Examiners. 
The studies outlined above demonstrate that only one study showed a negative impact to PBL (Adibi et al. 2007). This study demonstrated that a lecture followed by a practical seminar resulted in better performance than cased-based learning and PBL. Actual differences were just over 10\% which represents a possible shift from one grade boundary to another and is therefore not insignificant. The details of the two groups however are not completely clear. It seems both groups received the same lecture and then either a hands-on practical examination based seminar or cased-based and PBL in small groups. It is not clear from the manuscript whether the hands-on practical seminar was run as a didactic sessions or involved the use of PBL elements, however this context (practical application of anatomy) seemed to serve a better environment for learning.

The other studies reviewed demonstrated that PBL resulted in a greater score in anatomy exams in four studies (Khaki et al. 2007; Cowan et al. 2010; Loffler et al. 2011; Vasan et al. 2011) or no difference in five studies (Last et al. 2001; Prince et al. 2003; Nieder et al. 2005; Khalil et al. 2010; Azer et al. 2011). The actual magnitude of the gains demonstrated by these studies were in the region of $8-17 \%$ which would result in a likely shift up a grade boundary. It is important to highlight the actual difference as such effect may be insignificant despite a result of statistical significance. In the case of these studies however both statistical and meaningful differences were observed. However the effect was not universal across all studies. The most comprehensive study investigating the effect of PBL on anatomy knowledge is offered by Prince et al (2003). This study utilised eight entire medical schools resulting in a large cohort being included in the study. Direct comparison was made between the performances of these medical schools students to a standardised exam. This investigation demonstrated that the scores were equivocal across the examination for all schools regardless of teaching style.

In summary it seems that students educated using PBL to acquire anatomy knowledge are not at a disadvantage to others on more traditional programmes. However it appears that there is questionable benefit to using PBL to learn anatomy either, in terms of exam performance. These findings are in line with other reviews on PBL where little enhancement of student performance is noted (Colliver 2000; Vernon and Blake, 1993). However this could be viewed as there being no difference in performance between PBL and more traditional teaching methods for anatomy. This lack of difference suggests that either method is effective for acquiring knowledge to pass exams, however no insight is provided as to whether a PBL curriculum enhances learning in other ways not measurable by commonly employed multiple choice examinations. PBL is an active learning style resulting in students searching, acquiring and synthesising information to ultimately apply in clinical situations. It is therefore possible that many alternate skills are being developed by such active approaches (Gunn et al. 2012). The studies reviewed did not investigate such issues but it is something worthy of further consideration. One such variable may be student satisfaction. Indeed many universities conduct audits of student satisfaction as a key outcome measure and in all studies which measure enjoyment and satisfaction, it was demonstrated that students preferred a PBL approach. A previous meta-analysis investigating the efficacy of PBL across wider curriculum areas indeed allude to PBL based teaching resulting in positive scores relating to student attitudes, attendance and mood and it is believed this is where the advantages in a PBL approach are to be found (Vernon and Blake 1993)..

A key limitation to this work is that the definition of what constitutes PBL is unclear. This review used a pragmatic approach by employing the PBL search term and including those articles which self-declare they operate PBL. Other active learning approaches built around a central problem could be construed as PBL yet will not be incorporated as they did not define the approach as PBL. Indeed perhaps a wider question might be whether any active learning approach around a central 'problem' could be termed at PBL? This work was further limited to a search of only Medline. This database houses only strong medical journals and is therefore the ideal database for high quality manuscripts relating to anatomy. It is not clear if similar results would be obtained from other database searches.

\section{Conclusion}

The results of this review suggest that PBL offers no disadvantage over a more traditional curriculum if exam performance is measured, however PBL does not seem to result in greater performance compared with traditional methods. PBL may facilitate the development of other skills of learning although this has yet to be investigated relating specifically to anatomy. It is almost universal that students enjoy PBL based learning with respect to anatomy.

\section{References}

Adibi, I., Hasani, N., Ashoorioun, V., Sadrearhami, S., \& Monajemi, A.R. (2007). Integrating physical examination and trunk anatomy; a new course for second year medical students. Medical Teacher, 29(9), 975-977. http://dx.doi.org/10.1080/01421590701589219

Azer, S.A. (2011). Learning surface anatomy: Which learning approach is effective in an integrated PBL curriculum? Medical Teacher, 33(1), 78-80. http://dx.doi.org/10.3109/0142159X.2011.530704 
Bergman, E.M. (2011). Why don't they know enough about anatomy? A narrative review. Medical Teacher, 33(5), 403-409. http://dx.doi.org/10.3109/0142159X.2010.536276

Colliver, J. (2000). Effectiveness of problem-based learning curricula: research and theory. Academic Medicine, 75(3), 259-266. http://dx.doi.org/10.1097/00001888-200003000-00017

Cowan, M., Arain, N.N., Assale, T.S.A., Assi, A.H., Albar, R.A.A., \& Ganguly, P.K. (2010). Student-centred integrated anatomy resource sessions at Alfaisal University. Anatomical Sciences Education, 3(5), 272-275. http://dx.doi.org/10.1002/ase.176

Dolmans, D.H.J.M., de Grave, W., Wolfhagan, I.H.A.P. (2005). Problem-based learning: future challenges for educational practice and research. Medical Education, 39(7), 732-741. http://dx.doi.org/10.1111/j.1365-2929.2005.02205.x

Gunn, H., Hunter, H., \& Haas, B. (2012). Problem based learning in physiotherapy education: a practice perspective. Physiotherapy, 98(4), 335-340. http://dx.doi.org/10.1016/j.physio.2011.05.005

Khaki, A.A., Tubbs, R.S., Zarrintan, S., Khamnei, H.J., Shoja, M.M., Sadeghi, H., \& Ahmadi, M. (2007). The first year medical students' perception of and satisfaction from problem-based learning compared to traditional teaching in gross anatomy: Introducing problem-based anatomy into a traditional curriculum in Iran. International Journal of Health Sciences, 1(1), 113-118.

Khalil, M.K., Nelson, L.D., \& Kibble, J.D. (2010). The use of self-learning modules to facilitate learning of basic science concepts in an integrated medical curriculum. Anatomical Sciences Education, 3(5), 219-226. http://dx.doi.org/10.1002/ase.177

Koh, G.C-H., Khoo, H.E., Wong, M.L., \& Koh, D. (2008). The effects of problem-based learning during medical school on physician competency: a systematic review. Canadian Medical Association Journal, 178(1), 34-41. http://dx.doi.org/10.1503/cmaj.070565

Krontiris-Litowitz, J. (2008). Using truncated lectures, conceptual exercises, and manipulatives to improve learning in the neuroanatomy classroom. Advances in Physiology Education, 32(2), 152-156. http://dx.doi.org/10.1152/advan.00103.2007

Last, K.S., Appleton, J., Stevenson, H. (2011). Basic science knowledge of dental students on conventional and problem-based learning (PBL) course at Liverpool. European Journal of Dental Education, 5(4), 148-154. http://dx.doi.org/10.1034/j.1600-0579.2001.50402.x

Loffler, S., Feja, C., Widman, J., Claus, I., Von Lindeman, K., \& Eisnach, K. (2011). Interactive versus reproductive learning, a comparison of medical school graduates with participants of a postgraduate CPD session. GMS Zeitschrift fur Medizinische Ausbildung, 28(4), Doc 57.

Nieder, G.L., Parmelee, D.X., Stolfi, A., \& Hudes, P.D. (2005). Team-based learning in a medical gross anatomy and embryology course. Clinical Anatomy, 18(1), 56-63. http://dx.doi.org/10.1002/ca.20040

NNodim, J.O., Ohanaka, E.C., \& Osuji, C.U. (1996). A follow-up comparative study of two modes of learning human anatomy: By dissection and from prosections. Clinical Anatomy, 9(4), 258-262. http://dx.doi.org/10.1002/(SICI)1098-2353(1996)9:4<258::AID-CA8>3.0.CO;2-A

Prince, K.J.A.H., van Mameren, H., Hylkema, N., Drukker, J., Scherpbier, A.J.J.A., \& van der Vleuten, C.P.M. (2003). Does problem-based learning lead to deficiencies in basic science knowledge? An empirical case on anatomy. Medical Education, 37(1), 15-21. http://dx.doi.org/10.1046/j.1365-2923.2003.01402.x

Slavich, G.M., \& Zimbardo, P.G. (2012). Transformation teaching: Theoretical underpinnings, basic principles, and core methods. Educational Psychology Reviews, 24(4), 569-608. http://dx.doi.org/10.1007/s10648-012-9199-6

Vasan, N.S., DeFouw, D.O., \& Compton, S. (2011). Team-based learning in anatomy: An efficient, effective, and economical strategy. Anatomical Sciences Education, 4(6), 333-339. http://dx.doi.org/10.1002/ase.257

Vernon, D.T.A., \& Blake, R.L. (1993). Problem-based learning work? A meta-analysis of evaluative research. Academic Medicine, 68(7), 550-563. http://dx.doi.org/10.1097/00001888-199307000-00015

Ward, P.J. (2011). First year medical students' approaches to study and their outcomes in a gross anatomy course. Clinical Anatomy, 24(1), 120-127. http://dx.doi.org/10.1002/ca.21071

\section{$(\mathrm{cc}) \mathrm{Br}$}

This work is licensed under a Creative Commons Attribution 3.0 License. 